\section{The World} Trade

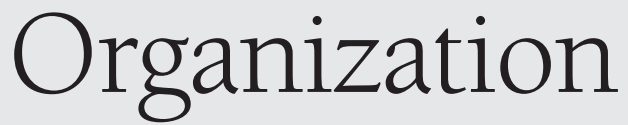
and

Competition Policy:

Implications for Developing Countries

\section{Peter Holmes}

IDS Bulletin Vol 34 No 22003

\section{Is there a need for global rules?}

Concerns about competition and trade have a long pedigree, back to Adam Smith. The 1947 Havana Charter of the abortive International Trade Organisation (ITO) included a requirement of members to police international restrictive business practices:

\begin{abstract}
Each Member shall take appropriate measures and shall cooperate with the Organisation to prevent, on the part of private or public commercial enterprises, business practices affecting international trade which restrain competition, limit access to markets, or foster monopolistic control, whenever such practices have harmful effects on the expansion of production or trade and interfere with the achievement of any of the other objectives set forth in Article 1 (UN 1947: Article 46, para. 1).
\end{abstract}

The Havana Charter would have left the "appropriate means" up to the member. The ITO as an organisation would have been called upon to investigate any complaints not resolved by consultation and make recommendations for action, but had no provision for a judicial system. It allowed for intergovernmental cooperation, and also provided a means for dealing with disputes in the service sector. The aim of today's World Trade Organization (WTO) discussions remains that of preventing private business practices from nullifying the benefits of the removal of governmental barriers to trade, even if the proposed means of achieving this aim are very different.

The topic "trade and competition policy" was put on the WTO agenda by the Singapore Ministerial meeting in 1996. A decision was taken to set up a working group to consider this interface. The working group is strictly for discussions only but its work has influenced the attitudes of WTO members towards the possibility of such negotiations and its reports give a valuable account of the evolution of the debate. ${ }^{2}$

A fundamental requirement to justify a multilateral agreement on competition must be that, in some senses, anti-competitive practices in one jurisdiction may have spillover effects in the global economy, as may national policies towards them. These are admirably reviewed in WTO (1997). But 
it does not follow that the existence of spillovers automatically means that a WTO agreement could actually solve the problems created.

We must ask first: is there evidence that cross-border anti-competitive behaviour is a problem? This seems to be agreed. However, three further questions arise:

1. Why cannot national governments take the necessary action?

2. What advantages does a multilateral agreement have over other forms of cross-border cooperation?

3. What forms should appropriate action take?

\subsection{Evidence on anti-competitive behaviour}

In answer to the first question there is powerful evidence that cross-border cartels are active and are not being adequately policed. In the 1990s the United States (US) Department of Justice became enormously active investigating and prosecuting cartels in industries such as vitamins, steel, and animal feeds. They uncovered evidence on a massive scale of global violations. The Citric Acid and Lysine cartels involved global markets of around US\$2 billion in the late 1990s. These developments prompted the Department of Justice to set up an International Competition Policy Advisory Committee (ICPAC). Its report (ICPAC 2000) found that cartels existed on a large scale.

Extensive work at the World Bank carried out and reviewed by Evenett suggests that nearly 7 per cent of imports into developing countries were in sectors where firms had been found by the US authorities to be involved in cartels. Evenett and Clarke (2002) show evidence that indicates that the impact of the international vitamins cartel prosecuted by the USA authorities was more serious in those developing countries that had no competition law.

\subsection{Reasons for intervening}

It is very important to distinguish two different reasons for attempting to curb anti-competitive activity because WTO members attribute different weight to them. They may involve market access; that is to say where private barriers to entry have been created by local firms against the will of certain foreign suppliers. Or they may involve pure international antitrust issues, where collusive or monopolistic behaviour by all firms is directed explicitly against consumers. In both cases consumers lose out, but a solution that "shares" markets may satisfy exporters (and hence, the instigators of the enquiry), but it does nothing for consumers. In neither case (although for different reasons) will uncoordinated action by domestic competition authorities solve the problem.

\section{Market access}

Anti-competitive collusion in a domestic market may be a very effective way to keep out imports, especially if distributors and wholesalers are involved. US policy makers and business circles expressed great frustration at US exporters' failed attempts to gain access to the Japanese market. From the mid-1980s on, the USA argued that the Japanese authorities had tolerated their own firms engaging in anti-competitive business practices, in particular through vertical integration between producers and distributors. A vast legal and economic literature emerged on whether Japan's markets were relatively more closed than other nations' markets, with little agreement emerging (Evenett and Suslow (2000) survey much of this debate).

In the early years of the establishment of the European Common Market (EEC), the need to ensure market access led to the establishment of a supra-national competition policy with the goal of preventing private actions causing distortions to trade between member states. In 1957, only Germany had a vigorous domestic competition policy. The Rome Treaty gave the European Commission powers to intervene directly and control anti-competitive behaviour by firms. This addressed the problem identified in the Havana Charter, but went further than the Charter in giving the executive the authority to act, not merely to report and recommend.

The jurisdiction of the European Commission was, and strictly speaking still is, limited to practices affecting cross-border trade. The EEC did not create an internal competition regime for its 
members. At that time, market access considerations led to a focus on the interests of exporters rather than consumers, but the effect has been positive for consumers as well as producers.

At the global level there is a further problem. A supra-national authority is unthinkable. ${ }^{3}$ The government in the exporting state has no jurisdiction in the "protected" market. And the competition authorities in the target market are, by definition, unable or unwilling to remove the barriers.

It is not surprising that when the view emerged that inadequate competition policy enforcement could undermine the expected market access gains from trade reforms, some began to argue that international disciplines on competition policies were necessary to ensure market access. It was natural to think then of this taking place within the WTO: bargaining over market access concessions in multilateral trade negotiations has been the time honoured and highly effective means of lowering border barriers. But by 1996, the USA had come to the conclusion that it could use its own unilateral and bilateral instruments to achieve these ends. Consequently, the demand that trade and competition should be on the post-Singapore WTO agenda came essentially from the European Union (EU).

\section{Antitrust}

International antitrust concerns primarily relate to the effect on consumer welfare of agreements or acts by dominant firms or cartels. They may, for example, charge excessive prices for exports. A dominant firm or cartel may also use power in one market to leverage its position in another, e.g. by predatory behaviour.

The antitrust remedy is likely to be different from that for market access. Indeed, the dynamics are almost exactly opposite. In the case of market access the problems are that the authority for the market in which the anti-competitive behaviour occurs is unwilling to act, while the authority that wishes to act has no jurisdiction. With antitrust the problem is that the authority of the economy experiencing the anti-competitive behaviour has jurisdiction but is unable in practice to act, while the other authority has the means, but is unwilling to do so.
Evidently, very different and complementary WTO rules would be needed to deal with these two situations. And this dichotomy has direct relevance to the issues raised in the Bulletin because there is a tendency for developing countries to focus on one cause and the industrialised countries on the other. Developing countries are mainly concerned about abuses by Northern exporters, while the EU and the USA's concern is about import cartels.

The cross-border effect in the export cartel is failure by the home jurisdiction to act against the anticompetitive behaviour of "its firms" in another market. Consider also the case of international mergers, which pose problems that were not foreseen when the General Agreement on Tariffs and Trade (GATT) was created in 1947. A merger between two firms may be allowed by the competition authorities in the "home" market because there remains plenty of domestic competition. But this may not be true of the markets in which their subsidiaries operate. There, the new combined entity may have a dominant position.

National competition authorities have as their objective only the interests of their own jurisdiction. Thus, while the EU and the USA take into account in their decisions the effects on their economies of actions taken elsewhere, they do not consider the effect on foreign markets of actions by their firms; these are captured if at all only as a corollary of regulation of activities on the domestic market. Indeed, it is not unusual for competition laws specifically to exclude sectors of activity where foreigners may be the main victims of anticompetitive practice. Shipping conferences, for example, have traditionally been exempted, and many jurisdictions exempt export cartels either explicitly or implicitly. ${ }^{4}$ But many commentators have observed that even if there were no such exemptions the EU or the USA governments could not easily prosecute their own firms for harm done to consumers elsewhere.

If governments in the parent firm's home country cannot act, why cannot those in countries where the affiliates operate? The answer is they face a major practical problem. It is unlikely that governments in the affected country will be able to get the evidence needed to pursue infringers even if they have effective laws. The capacity of competition 
authorities to assess adequately all the factors in transnational mergers may well be limited even if there is no problem of a willingness to act. The increasing number of international mergers and strategic alliances where the authorities are forced to rely on whatever information the parties supply clearly raises the question of the need for enhanced cooperation.

\subsection{The scope for voluntary bilateral agreements}

\section{Information sharing}

Why cannot bilaterally agreed cooperation resolve the information problem? The US position has long been that bilateral agreements are the solution. And there are numerous bilateral agreements between the major industrial countries that attempt to do this. The EU-USA agreement (1998), for example, provides for "positive comity". This allows requests for other jurisdictions to take action under their own laws when the requesting party's interests are affected.

The EU has made a point of incorporating competition provisions into nearly all its recent preferential trade agreements with countries of Central and Eastern Europe (CEECs). These ban:

(i) all agreements between undertakings, decisions by associations of undertakings and concerted practices between undertakings which have as their object or effect the prevention, restriction or distortion of competition; and (ii) abuse by one or more undertakings of a dominant position in the territories of the Community or of [the partner country] as a whole or in a substantial part thereof, if they may affect trade between the two partners (EC-Poland 1993).

The agreements declare that the meaning of these terms shall be that used in the EU under what are now Articles 81 and 82 (formerly Articles 85 and 86). This has been widely seen as dictation by the $\mathrm{EU}$ of what form of domestic competition policy the partners should have, even though it technically leaves the associates free to achieve this end by their own means. However, its relationship with the CEECs means that the EU can make such demands, largely due to the carrot of membership and the stick of exclusion.
ICPAC (2000) and Janow (2000) show the weakness of more conventional bilateral agreements between sovereign states. There is no obligation to exchange confidential information in fact there is no obligation to do anything - merely a right of request, even when the agreement includes the so-called "positive comity" provision. The requested jurisdiction can act only on matters, which would be illegal under its own laws.

As a result, the USA has sought to replace the cooperation agreements with Multilateral Legal Assistance Treaties (MLATs). Obligations under an MLAT would be much stronger than in the EU-US agreement. But there are few of these as yet, and in particular developing countries rarely secure cooperation agreements with their major trading partners in the North. The main exception is the USA-Brazil agreement (1999).

Yet the practical difficulties of bilateral agreements may be overstated. Despite misgivings, Janow (2000) also reports that the EU and US authorities routinely manage to agree on common definitions of the relevant market where both are looking at the same case.

Nonetheless, we cannot rule out conflicts such as occurred in the GE-Honeywell case, where the EU blocked a merger approved in the USA, and moreover there are almost no bilateral agreements with developing countries. The EU-South Africa Trade, Development and Cooperation Agreement of 1999 (European Council 1999) contains similar provisions to the EU-Poland accord, but does not spell out the detailed competition policy criteria to be used by South Africa. The EU-Mexico Free Trade Agreement of 2000 contains similarly vague provisions (EC-Mexico Joint Council 2000: Article 39 and Annexe XV).

It may be unrealistic to assume that a full web of bilateral arrangements could be set up, given the lack of progress so far. All in all, the evidence that existing procedures are adequate is less than compelling. The big questions are whether:

- feasible multilateral agreements without some sort of asymmetry in favour of developing countries could help development goals, and whether 
- asymmetrical agreements are feasible, given that developing countries have little to offer the EU and the USA by way of cooperation.

So far, as we noted, the only significant developed-developing country cooperation agreement is that between the USA and Brazil. Some disappointment has been expressed over the usefulness of this, and the key question is whether a WTO agreement would reflect the existing asymmetries or be a way to allow developing countries to get round them by "free riding" on some newly created multilateral obligations that developed countries would take on.

\section{Free trade}

But is competition policy the only, or the best, route to overcoming anti-competitive behaviour? It is sometimes asserted that, in the absence of any government-sponsored barriers to trade and to investment, national competition policy is unnecessary.

Empirical studies have certainly borne out the claim that trade reform helps reduce the exercise of market power by domestic firms (Tybout 2000). However, it has not been shown that removing tariffs eliminates all domestic market power. Even if such a finding did emerge, it would apply only to markets in which goods are tradable. Although it could be argued that open foreign direct investment regimes could inject competitive pressures into non-tradable sectors, the EU and US antitrust experience demonstrates that even in competitive economies some markets remain open to anti-competitive practices.

Thus, the available empirical evidence suggests that trade liberalisation is not a perfect substitute for an active competition policy. Although liberal trade is a very important and powerful pro-competitive policy, there remains a place for an active competition policy, particularly in larger developing countries.

\subsection{Could a multilateral accord overcome these problems?}

We have thus a case for some form of international agreement on the regulation of competition in the world economy, and the WTO seems a natural place for this if there is to be a binding element. Although the EU is busy creating a web of bilateral agreements, there is a strong argument that so many overlapping and possibly inconsistent agreements are inadequate and inefficient.

\section{Objections on grounds of practicality}

US officials point out that a multilateral agreement is not an alternative to bilaterals. The Clinton administration argued for stronger bilateral and voluntary cooperation outside the WTO. ICPAC (2000) highlighted the global dimension of antitrust and the weaknesses of existing arrangements, but argued firmly against WTO involvement:

At this juncture, the majority of the Advisory Committee believes that the WTO as a forum for review of private restraints is not appropriate. Given the possible risks, and the lack of international consensus on the content or appropriateness of rules or dispute settlement in this area, this Advisory Committee believes that the WTO should not develop new competition rules under its umbrella (ICPAC 2000).

The experience with even strong bilateral agreements has served to emphasise their problems in the eyes of critics. The USA has passed an International Antitrust Enforcement Act providing a framework for bilateral cooperation, but so far it has spawned only one agreement: with Australia.

\section{Objections on grounds of political non-feasibility}

The failure of bilateral agreements with teeth to spread may reflect an underlying resistance to cross-border regulation, an objection that would apply a fortiori to a meaningful WTO accord. EU industry, for example, is strongly opposed to any agreements that would oblige the $\mathrm{EU}$ to give confidential information to the US authorities. Business fears that information given to the Commission, if shared, might lead to penalties in the USA, including criminal imprisonment.

Although the USA recently proposed an Organisation for Economic Cooperation and Development (OECD) agreement that would enjoin members to act against all cartels which were already illegal under their existing laws, this 
did not include a commitment to police all export cartels. Even the EU, desirous as it is to see enhanced cooperation, has some problems with a commitment to police the anti-competitive behaviour of its own firms in export markets.

There has been quite strong political reticence from the competition policy community itself. Competition specialists do not want their turf taken over by trade officials. They are afraid that certain mercantilist goals may supersede efficiency aims. Some developing countries, on the other hand, worry that efficiency-only goals would predominate in a WTO competition agreement. Nevertheless, many competition laws contain aims other than competitive efficiency, and so there is no a priori reason why this should not also be the case at the multilateral level. EU policy supports the survival of small firms, and South African law requires competition authorities to take account of the interest of historically disadvantaged people.

\section{Advantages of multilateralism}

In many respects, a multilateral accord would suffer from the same problems as a bilateral agreement, but in other regards, it may be able to overcome problems. International antitrust enforcement is in large part a public good. Any country that offers to take other countries' interests into account without an assurance that others will do the same incurs a cost. A multilateral agreement would increase this assurance.

But is it the case that everyone is likely to be willing to adopt effective antitrust enforcement if others agree to do the same? As we noted, there are certain interests that are against more effective international enforcement. Nevertheless, almost all governments see the desirability of competitive markets. The fact that there are real differences of opinion does not mean that agreement is impossible, but it helps explain why it has not yet been reached.

Could we devise a WTO regime with benefits greater than costs for everyone? If so what form would it take? What is clear from the discussions is that the idea of an international agency reporting on, and eventually policing, international competition issues is not even being discussed at the WTO. What is being discussed is much more modest.
The EU would like all (or nearly all) WTO members to have their own competition law, and calls for the creation of stronger modalities for cooperation. It does not seek a global equivalent of its Competition Directorate. Fox (1999) argues that the international competition issue should be split: there should be a general WTO obligation to have a competition law that ensures market access is not unreasonably impaired, but all other matters should be left to other fora.

Even a minimalist WTO role of this kind causes some fears. Many analysts have argued that there are substantial differences in philosophy between jurisdictions (and between trade and competition officials). But such divergence may be disappearing. As discussions have proceeded at the WTO and the OECD, there has been a clarification of what is commonly agreed and what is not. There is a consensus that non-discrimination and transparency are key disciplines that everyone should respect, though even these concepts cause problems for some players. The EU is seeking to place the emphasis on ensuring transparency. This might mean allowing governments quite a lot of freedom to carve out exceptions from nondiscrimination, e.g. in providing that take-overs on a certain sector would only be allowed for national firms, but with WTO rules insisting that all such exceptions were registered as part of the country's commitment at the WTO. There is a similar logic in the General Agreement on Trade in Services (GATS) agreement.

\section{Should the rules apply to developing countries?}

The previous section showed that a cross-border competition policy may be needed for antitrust remedies in some cases. Developing countries might consider that they had most to gain from a regime that would constrain international cartels and the exercise of undue market power by firms from developed country jurisdictions. On the other hand, they see little gain from an obligation to have their own competition laws, which is something they can choose to do (or not to do) for themselves.

In practice, developing countries are currently divided over the desirability of a WTO 
competition agreement. South Africa and some Latin Americans are favourably inclined, but Asian countries are more sceptical. Officially India has argued that, while they recognise the multilateral dimension of competition policy and support the work of the United Nations Conference on Trade and Development (UNCTAD), they want to see some of the basic systemic issues of the WTO sorted out before new areas are included in negotiations. But there are influential counter views. The Consumer Unity and Trust Society (CUTS) Institute in Jaipur has argued on the basis of extensive research that the problem for India is not that WTO rules will force an unwelcome new approach; it is that its own authorities are insufficiently active in enforcing even existing laws (see CUTS 2001).

What is being proposed by the EU, and so far there are no explicit alternative agendas on the table, is essentially that a minimalist WTO regime should be established with two elements:

- Certain core obligations for domestic competition policy for all WTO members (subject to potential special and differential treatment (SDT) opt-outs), and

\section{- A framework for voluntary international cooperation.}

Such an agreement, obliging members to have a competition law of some kind, would have an immediate effect only on those countries that do not have a competition law at present. These are mainly developing countries plus those, such as Hong Kong, who argue that an open trade regime is sufficient to guarantee fully competitive markets. ${ }^{5}$ Why would developing countries need a WTO competition code to adopt domestic laws that they could adopt unilaterally?

An initial question, therefore, is how far developing countries should be, and are, introducing domestic competition policies; only if some are not doing so would the first element provide any new commitment. A second question is what would they have to gain from voluntary cooperation. Finally, how do the rules need to be adapted to ensure maximum benefits for developing countries and minimal compliance costs?

\subsection{Is competition policy good for development?}

The tally of countries with competition laws shows the number increasing every year. Competition policy is spreading in sub-Saharan Africa, and there is a growing interest in the need for vigorous competition policy to assist the transition from economies dominated by parastatals. South Africa has been in the vanguard of promoting the use of competition policy as a way of achieving both economic and social ends, to make industry more competitive for export markets and to deconcentrate power. Developing countries are also increasingly aware of the danger posed by international cartels and anti-competitive practices regarding distribution.

Should other developing countries follow suit? Although there is little empirical evidence on the link between competition and growth, some studies do find a significant correlation between countries' growth and their use of competition policy (Tybout 2000; Dutz and Hayri 2000). Some other authors have been more sceptical however, stressing the costs (see McCulloch et al. 2002). But Evenett and Clarke (2002) argue that the benefits of deterring even one anti-competitive case such as the vitamins cartel would pay for the running of a competition office. A study on Peru (Caceres 2000) argued that the economic benefits were about six times the costs.

\subsection{What about World Trade Organization rules?}

While there exists a prima facie case that it would be in developing countries' interests to have a domestic competition law if they do not already do so, real difficulties are created for some by several core principles that would be in a WTO agreement. "National treatment" is a bugbear to some. This means that a country's law must treat foreign and domestic firms equally. India argues that this is equal treatment of unequals. The main concern expressed is that multinational firms with deep pockets will be able to engage in unfair competition. Many of these concerns could be dealt with by targeting the kinds of behaviour feared (which could be undertaken by powerful domestic firms too). But the one concern that must be faced head on is where the government has a 
political preference to favour ownership of industry by nationals, or a particular group of the local population.

While a WTO commitment to have a domestic competition policy would not address global antitrust issues directly, it could be seen as a necessary condition. There is little scope for cooperation on cartels if a country does not have a competition law. And the goal of better international cooperation in antitrust (albeit voluntary) could be a positive attraction for developing countries. "Positive comity" would not go very far, but a real commitment to share information and expertise where cartels had been discovered in industrial countries could be a major benefit. It is a benefit however, that could be taken up only by a country that had a competition law.

A step further would be if countries that agree to have a competition law obtain significant additional rights, above all in terms of cooperation. This is more likely to involve discussion and exchange of information than an attempt to address the really sensitive matters such as multijurisdictional review of mergers. No country is likely to give up the right to review cases, but there are things that can usefully be done even here, e.g. agreeing ways to define relevant markets, etc.

A particularly interesting area for developing countries, though a very sensitive one, is the use of competition policy to curb the potential abuse of patents. The Agreement on Trade-Related Aspects on Intellectual Property Rights (TRIPS) provides a right for host and importing countries to control patent abuses through competition law. This is a little-used provision, which should be reaffirmed and strengthened in any competition agreement. But it is one that cannot easily be exploited by a country that has no competition law.

\section{What kind of World Trade Organization policy is on the agenda?}

There exists a modest case, therefore, that a multilateral requirement about domestic competition policies would not, in itself, be unduly onerous and could have advantages. Since the advantage is primarily the ability to benefit from other, voluntary, cooperation, its scale will depend upon how much cooperation WTO members are willing to provide in practice. Hence, there is a risk: mandatory provisions now in return for nonmandatory gains later. And, with the Uruguay Round experience behind them, developing countries are clearly risk averse in the WTO. They fear that proposals, which look modest now, might grow into something more burdensome, and that the benefits dangled before them may disappear once their signature is on the document.

What danger is there that this would be the thin end of an unwelcome wedge? The key choice for developing countries is whether to take the gamble that negotiations now offer an opportunity to strengthen competitive disciplines in global markets or whether they should merely opt to keep discussions going in the working group.

The basic proposals on the table reflected in documents of the WTO working group seek a binding commitment that members introduce some sort of competition law, but of a rather limited nature and potentially subject to exemptions of a developmental kind. Dispute settlement would not apply to the way in which policy was applied, but only to whether a member state's laws were de jure compatible with the commitments it had signed up to. Alongside this mandatory requirement would be a legal framework for voluntary international cooperation. The problem for critics is that developing countries would acquire an additional legal obligation (however diluted) to adopt a competition law, while for developed countries there would be only a moral obligation to share information, etc.

\subsection{The positions of the big players}

Hence, it seems likely that there will need to be further development of current positions before a deal is ripe for the making. How far would this need to go? This section summarises the positions of three big players and then compares two of them: the EU and India, to determine whether or not the gap is bridgeable.

\section{The EU}

In 2001, the Director General for Trade at the Commission Mogens Peter Carl said: ${ }^{6}$ 
What we are proposing is to introduce, into the WTO, provisions that require its members to adopt certain minimum standards and core principles as it relates to their domestic competition laws and regulations and to respect certain requirements of international cooperation between competition authorities. The establishment of a domestic competition policy and a competition authority with sufficient enforcement powers remain the basis, in the absence of which a country would not be able to address anti-competitive practices of a domestic or international character (Carl 2001).

The EU's aims, he argued, were the following:

More specifically, we suggest that WTO negotiations should focus on three key issues:

1. Core principles of domestic competition law and policy.

2. Cooperation between competition authorities, including both specific cases and more general cooperation and exchange of information.

3. Technical assistance and capacity-building for the reinforcement of competition institutions in developing countries (Carl 2001).

The EU acknowledges that there are international differences in approach, but seeks to build on common ground by saying that every country's competition law must ban "hard-core cartels". ${ }^{7}$ The Commission sees this as the central plank in any effective multilateral competition regime. It argues strongly that the adoption of common core principles, to include non-discrimination and transparency, should not conflict with other development objectives. That is to say, any competition commitments should not affect other development policies, which would still be subject to normal WTO disciplines.

The Commission has also suggested that countries wishing to exclude sectors from competition rules or from national treatment provisions should be free to do so, subject only to the proviso that exclusions must be transparent and hence predictable for economic actors. Their model is perhaps similar to some elements in the GATS. It is worth remembering that WTO members are already subject to "national treatment" rules for all policies that might affect trade (under GATT Article III). It is not clear if the EU plan would actually widen these obligations; in fact the EU plan would probably narrow the obligations by allowing exemptions.

The EU places great stress on the benefits of a framework for cooperation, which they argue would be helped by some agreement on common principles. They stress, however, that the requirement to undertake cooperation will be "voluntary" in that it will be to consider requests not to act on them. This gets around the problem of onerous procedural obligations, but it leaves open the complaint that the EU can also refuse assistance to developing countries, even though one of its aims is said to 'include responding to the longstanding developing country concerns about the importance of assistance by "home" competition authorities in those cases in which foreign firms may be engaged in anti-competitive practices with an impact on developing country markets' (EC 2001).

\section{The USA}

The US view, which was sceptical about WTO involvement under Clinton, has moved on under Bush. Robert Zoellick has said: ${ }^{8}$

In competition policy, U.S. trade and antitrust authorities recognize the significance of the issue. Therefore, we are working to understand more clearly what the EU seeks, and are discussing with the EU how it can accommodate the concerns of the United States and other countries.

But Zoellick also expresses doubts:

What is not clear to us, however, is how competition obligations based on the core principles should be assessed; for example, the important question of how dispute settlement might operate or whether other forms of oversight such as peer review might be more satisfactory. ${ }^{8}$

The EU responds that dispute settlement will not cover cases and enforcement, but only the 
consistency of laws with commitments on core principles; for the rest it favours peer review. The EU does have something to offer the USA, namely enhanced antitrust enforcement cooperation. It might need to go further and be ready to exchange confidential information with the USA, although whether this is a priority for the USA will have to be determined.

\section{India}

India was in the past a supporter of a trade and competition agreement, but is now the leading opponent. Its main argument is that the kind of cooperation offered by the EU would not amount to anything worthwhile.

A recent Indian paper can be read almost as a statement of conditions under which it would subscribe to a global competition agreement.

Until such time as developed countries are willing to consider the impact of mergers on consumers in foreign countries, to rescind the exemption of export cartels in their competition laws, to give serious consideration to enforcing the UNCTAD Set of measures to control RBPs [restrictive business practices], and to extend the benefits of "positive comity" in competition law enforcement to developing countries, the latter will have to retain the right to challenge foreign mergers and RBPs that have an effect on domestic consumers (Government of India 2002).

\subsection{How far apart are the EU and India?}

How different is the Indian and the EU position? Let us consider the various elements of the Indian position in turn:

1. To consider the impact of mergers on consumers in foreign countries.

2. To rescind the exemption of export cartels in their competition laws.

3. To give serious consideration to enforcing the UNCTAD 'Set of Multilaterally Agreed Equitable Principles and Rules for the Control of Restrictive Business Practices' (UNCTAD 1980).
4. To extend the benefits of "positive comity" in competition law enforcement to developing countries.

Points 1, 2 and 4 go in the same direction: the Indians are asking for the EU and the USA to take account of foreign consumers in decisions on cartels and mergers. But the wording of the first two points is subtly different. Point 1 asks developed countries to 'consider the impact' of mergers, a soft demand. What is meant by 'consider'? Gathering information on the worldwide implications for competition is not the same as asking for mergers which do no harm at home to be stopped because they do harm elsewhere.

Point 2 asks for an end to the exemption of export cartels. What does this mean? It could be argued that it has to be interpreted literally. To the extent that domestic competition laws cover only measures with effect in the territory of the jurisdiction, the repeal of any explicit exemptions would do nothing for foreign countries. Only if there were a positive decision to take some sort of action against effects in external markets, or at least to allow action to be taken, would there be any benefit.

The question is how far would such a move have to go to be meaningful? Would it be enough to require firms found guilty of an infringement in one jurisdiction to file in full details of their worldwide activity? It is easier to see the EU acting against firms that have been shown to have done something that is illegal within the EU than against firms that have done nothing to harm EU consumers. Point 4, "positive comity", requires countries to take account of others' interests, but only to the extent of a country's own law. So if points 1 and 2 are applied in the sense of "positive comity", the EU would not be asked to prosecute firms for doing things not illegal in the EU.

Hence, India is implicitly asking for a ban on export cartels, which is not inconsistent with the EU position. It is more likely to be opposed by the USA. Though the EU seems at the moment to focus on domestic cartels and on supplying non-confidential information, it has said 'a WTO Member should inform other Members whose important trade interests may be affected by ongoing investigations and proceedings under its competition laws' (EC 
2002). The key point of controversy is over the extent of obligation. The EU paper specifically calls for voluntary cooperation for all kinds of international competition issues, except hard-core cartels, which would be subject to mandatory control. Hence unless a developing country had taken an exemption it would have a legal obligation to pursue cartels in its own market that might be keeping Northern firms out, but no equivalent right in relation to Northern export cartels.

Could this gap be bridged? We know that there is no mechanism to force the EU to act on complaints brought even by domestic consumers. It is hard to see any international agreement on hard-core cartels removing altogether the right of a competition authority not to investigate domestic complaints.

Perhaps the UNCTAD 'Set of Multilaterally Agreed Equitable Principles and Rules for the Control of Restrictive Business Practices' could provide a bridge, given India's support for it. It has a clear difference of language from the EU's proposals, but no obvious inconsistency with the traditional aims of competition policy.

The first aim of the Set is:

To ensure that restrictive business practices do not impede or negate the realization of benefits that should arise from the liberalization of tariff and non-tariff barriers affecting world trade, particularly those affecting the trade and development of developing countries (Part IV, Section A, para. 1).

Restrictive business practices by multinational corporations are given prominence, but they are not the exclusive target. The Set seeks to:

eliminate the disadvantages to trade and development which may result from the restrictive business practices of transnational corporations or other enterprises, and thus help to maximize benefits to international trade and particularly the trade and development of developing countries (Part IV, Section A, para. 4).

The Set's equivalent of SDT is quite modest:
In order to ensure the equitable application of the Set of Principles and Rules, States, particularly developed countries, should take into account in their control of restrictive business practices the development, financial and trade needs of developing countries, in particular of the least developed countries (Part IV, Section C, (iii)).

\section{Conclusion}

The implications of these ideas for SDT probably have more to do with rights than obligations if the EU's proposals can be taken at face value. The obligation on developing countries to adhere to competition law is not enormously onerous, and has lots of flexibility; particularly if there is room for exceptions. Countries would also have to think whether they really have some special need to ask for a national treatment carve-out.

But the big question is whether the provisions for voluntary information sharing and cooperation on the part of developed countries would really deliver something worth negotiating for. If this question is adequately addressed, there is a chance of a development friendly competition agreement. This might evolve into something more effective as years go by.

One possible approach would be to build upon the fact that, to take advantage of any opportunities provided by voluntary cooperation, a developing country would need to have in place an effective competition policy. SDT would then exempt developing countries from an initial obligation to introduce a basic competition law with core principles, but would also recognise the right of other WTO members (implicit in any voluntary undertakings) not to cooperate with countries lacking a competition policy if they wished. The WTO texts would establish the parameters of the required basic competition policy (and be negotiated by all WTO members). But the adoption of such a policy would proceed at the pace determined by each member to be in its interests, taking account inter alia of the cooperation perceived to be available from other members. 


\section{Notes}

1. This article draws heavily on earlier work with Rob Anderson of the WTO and Bernard Hoekman of the World Bank, who are responsible for many of the ideas but not for the remaining and newly introduced errors

2. On the pros and cons see WTO (2001).

3. Proposals on these lines in the 1990s were vigorously shot down: see Fikentscher et al. (1993) and Scherer (1994).

4. Some US experts believe that repealing the US Webb-Pomerene Act, which allows export cartels, would have no effect, as any adverse effects affecting

\section{References}

Bercero, I.G. and Amarasinha, S.D., 2001, 'Moving the trade and competition debate forward', Journal of International Economic Law, Vol 4 No 3: 481

Caceres, A., 2000, 'Indecopi's First Seven Years', in B. Boza (ed.), The Role of the State in Competition and Intellectual Property Policy in Latin America: towards an academic audit of Indecopi, Lima: Indecopi

Carl, M.P., 2001, 'Towards basic rules on trade-related competition policy', speech by Director General DG Trade, Brussels, 2 March, http://europa.eu.int/comm/ trade/speeches_articles/sp_mpc01.htm

CUTS, 2001, 'Let's be proactive on multilateral competition policy', Viewpoint, Jaipur: Consumer Unity and Trust Society, www.cuts.org/viewpntmcp.htm

Dutz, M.A. and Hayri, A., 2000, Does More Intense Competition Lead to Higher Growth?, Washington DC: World Bank, http://wbln0018.worldbank.org/ research/workpapers.nsf/

EC, 2002, 'Communication from the European Community and its Member States. A WTO Competition Agreement's Contribution to International Cooperation and Technical Assistance for Capacity-Building', WT/WGTCP/W/184, 22 April, Geneva: World Trade Organization, Working Group on the Interaction between Trade and Competition Policy, http://docsonline.wto.org

EC, 2001, 'Communication from the European Community and its Member States', WT/WGTCP/W/175, 26 July, Geneva: World Trade Organization, Working Group on the Interaction between Trade and Competition Policy, http://docsonline.wto.org

EC-Mexico Joint Council, 2000, 'Decision no 2/2000 of the EC/Mexico Joint Council of 23 March 2000 (covering trade in goods, government procurement, cooperation for competition, consultation on only foreigners are anyway legal in the USA, or indeed anywhere else.

5. This is the strongly held position of the Hong Kong government, but it is contested by the Hong Kong Consumer Council.

6. See also Bercero and Amarasinha (2001).

7. See especially the EU paper for the WTO 'International Hardcore Cartels and Cooperation under a WTO Framework Agreement on Competition', WT/WGTCP/W/193, 1 July 2002.

8. In a statement made on 17 July 2001, after meeting Pascal Lamy.

intellectual property rights, dispute settlement)', CE-MX 3854/00, http://europa.eu.int/comm/trade/ bilateral/fta.htm

EC-Poland, 1993, 'Europe Agreement between the European Communities and their Member States, of the One Part, and the Republic of Poland, of the Other Part', http://europa.eu.int/comm/competition/ international/3a05en.html

European Council, 1999, 'Agreement on Trade, Development and Cooperation between the European Community and its Member States, of the One Part, and the Republic of South Africa, of the Other Part', Brussels: Council of the European Union, http://europa.eu.int/comm/development/ south_africa/agreement.pdf

EU-USA, 1998, 'Agreement between the Government of the United States of America and the European Communities on the Application of Positive Comity Principles in the Enforcement of their Competition Laws', www.usdoj.gov/atr/public/international/docs/ 1781.htm

Evenett, S. and Clarke, J., 2002, The Deterrent Effects of National Anti-Cartel Laws: Evidence from the International Vitamins Cartel, Berne: World Trade Institute, www.worldtradeinstitute.ch/netscape4.html

Evenett, S. and Suslow, V., 2000, 'Private international cartels and their effect on developing countries' (with Margaret Levinstein), background paper for World Bank's World Development Report 2001

Fikentscher, W., Drexl, J., Fox, E.M., Fuchs, A., Heinemann, A., Immenga, U., Kunz-Hallstein, H.P., Petersmann, E.-U., Schluep, W.R., Shoda, A., Soltysinski, S.J. and Sullivan, L.A., 1993, 'Draft International Antitrust Code as a GATT-MTO-Plurilateral Trade Agreement', Antitrust \& Trade Regulation Report, Vol 65, No 1628, Special Supplement, 19 August 
Fox, E.M., 1999, 'Competition law and the millennium round', Journal of International Economic Law, Vol 2 No 4: 665-79

Government of India, 2002, 'Working Group on the Interaction between Trade and Competition Policy: Communication from India', WT/WGTCP/W/216, 26 September, Geneva: World Trade Organization, http://docsonline.wto.org

ICPAC, 2000, International Competition Policy Advisory Committee to the Attorney General and Assistant Attorney General for Antitrust: final report, Washington DC: International Competition Policy Advisory Committee, www.usdoj.gov/atr/icpac/finalreport.htm

Janow, M.E., 2000, 'Transatlantic Cooperation on Competition Policy' in S.J. Evenett, A. Lehmann, and B. Steil (eds), Antitrust Goes Global: what Future for Transatlantic Cooperation, Washington DC: Brookings Institution Press

McCulloch, N., Winters, L.A. and Cirera, X., 2002, Trade Liberalization and Poverty: a Handbook, London: Department for International Development and Centre for Economic Policy Research

Scherer, F.M., 1994, Competition Policies for an Integrated World Economy, Washington DC: Brookings Institution Press

Tybout, J.R., 2000, 'Manufacturing firms in developing countries: how well do they do, and why?', Journal of Economic Literature, Vol 38 No 1
UN, 1947, Havana Charter for an International Trade Organisation, adopted at the United Nations Conference on Trade and Employment, Havana, Cuba, www.globefield.com/havana.htm

UNCTAD 1980, The Set of Multilaterally Agreed Equitable Principles and Rules for the Control of Restrictive Business Practices, Geneva: United Nations Conference on Trade and Development, http://r0.unctad.org/en/subsites/cpolicy/docs/CPSet /cpsetp4.htm

USA-Brazil, 1999, 'Agreement Between the Government of the United States of America and the Government of the Federative Republic of Brazil Regarding Cooperation Between their Competition Authorities in the Enforcement of their Competition Laws', www.usdoj.gov/atr/public/ international/3776.htm

WTO, 2001, 'Report (2001) of the Working Group on the Interaction between Trade and Competition Policy to the General Council', WT/WGTCP/5, 8 October, Geneva: World Trade Organization, http://docsonline.wto.org

_, 1997, 'Special Study on Trade and Competition Policy' in WTO Annual Report - 1997, Geneva: World Trade Organization 